\title{
CRITICAL, LOGICAL \& CREATIVE THINKING IN A REFLECTIVE CLASSROOM PRACTICES
}

\author{
Suciana Wijirahayu \\ sucianawijirahayu@gmail.com \\ UHAMKA University, Indonesia \\ Hendro Priyatmoko \\ priatmokohendro@gmail.com \\ STBA LIA University, Indonesia \\ Siti Hadianti \\ Ositihadianti0@gmail.com
}

\begin{abstract}
It is not relatively new that higher order thinking skills (HOTS) have started to be implemented in educational process. HOTS are believed to prepare students better for the challenges both in advanced academic life and adult's work and responsibility in daily basis. However, does this phenomenon also happen in the learning of English skills? This study tries to explore the implementation of higher order thinking skills in three different English classrooms at Sofia University, Bulgaria namely Word Formation in Modern English, Varieties of Spoken English and The Principle of Literary Analysis. Data were gained from course description, classroom activities and assessment. The findings show that the lecturers employed strategies pertinent to HOTS, some of which are modeling of artful thinking skills, scaffolding, useful learning strategies with effective feedback, challenging tasks, and teacher-student problem solving of unfamiliar issues.
\end{abstract}

Keywords: higher order thinking skills/HOTS, teacher strategies, EFL, classroom practices

\section{INTRODUCTION}

It is important to have effective thinking skills in today's world that is becoming more complex. With the growing of information technology, people need to solve various problems and take decisions fast and efficiently. To help people survive in society, higher-order thinking skills (HOTS) are needed including critical, logical, reflective, metacognitive, and creative thinking. These will be activated when individuals encounter unfamiliar problems, uncertainties, questions, or dilemmas.

Many scholars have agreed with the value of teaching the skills to the students. So, it is hoped that the teachers do not only deliver knowledge to the students, but also teach them the strategies of how to think skillfully and effectively. As part of

IJET| Volume. 8, Issue 1. June 2019 
classroom practices, Wijirahayu (2017) reported that there is a relation between the language learning strategies employed by the students and the teaching strategies utilized by the teachers. It is therefore necessary for nowadays' language teachers to find strategies and techniques that use HOTS for their classroom to generate skillful and effective learners. In this study, the critical, logical and creative thinking analyzed as a reflection from individual experience in some classroom practices was explored.

\section{Review of Related Literature}

\section{A. Higher Order Thinking Skills}

Higher order thinking skill is often described as an ability to orchestrate various characteristics to handle particular situation such as unfamiliar problems, uncertainties, questions, or dilemma (Kings, Goodson, and Rohani, 2013). Brookhart (2010) defines higher order thinking in three different categories, in term of "transfer" (meaningful learning), "critical thinking" (artful thinking), and "problem solving" (specific goal reaching). In terms of transfer, education promotes retention of what have been learned and making sense of and use what have been learned. Additionally, critical thinking includes reasoning, questioning, and investigating. While problem solving involves problems to solve in order to reach a desired goal. Similarly, King, Goodson and Rohani states that higher order thinking skills include critical, logical, reflective, metacognitive, and creative thinking. Metacognition includes awareness of one's thinking processes, self-monitoring, and application of known heuristics and steps for thinking.

More importantly, higher order thinking is usually related with stages of thinking, the higher the stage the better. There are a lot of concepts and also terms used in describing higher order thinking. To compare different concepts and terms, there are three different theories from Haladyna, Gagne and Bloom shown in the following table:

Table 1. The HOTS terms used in Haladyna, Gagne and Bloom's theory

\begin{tabular}{|l|l|l|}
\hline Haladyna's terms & Gagné's terms & Bloom's terms \\
\hline facts & information & Knowledge/remembering \\
\hline concepts & concepts & Comprehension/understanding \\
\hline principles, procedures & rules & application \\
\hline critical thinking & problem solving & synthesis and evaluation \\
\hline creativity & no direct match & Creating \\
\hline
\end{tabular}




\section{B. Bloom's Taxonomy and Its Revision}

The new taxonomy comprises remembering, understanding, applying, analyzing, evaluating and creating. The first three aspects are categorized as LOTS (low order thinking skills) and the second three aspects are HOTS (high order thinking skills ) (Moore \& Stanley, 2010). In other words, HOTS is the highest part in Bloom's taxonomy of cognitive domain

Anderson and Krathwohl have their own revision toward Bloom's (2001). A major revision lies on "Knowledge and Cognitive Process". Knowledge deals with facts, concepts, procedures, or metacognition. Meanwhile the the concept of cognitive process is very much like except the order. The first level of cognitive dimension is called Remember involving recognizing or recalling facts and concepts. Understand involves basic comprehension, understanding newer theories of learning that emphasize students constructing their own meaning. Processes in this category include interpreting, exemplifying, classifying, summarizing, inferring, comparing, and explaining. Apply means to execute or implement a procedure to solve a problem. Application-level problems still usually have one best answer. Analyze means to break information into its parts, determining how the parts are related to each other and to the overall whole. The rocesses include differentiating, organizing, and attributing. Multiple correct responses are still likely in analysis-level tasks. Evaluate means judging the value of material and methods for given purposes, based on criteria. Processes include checking and criticizing. Create means putting disparate elements together to form a new whole, or reorganizing existing elements to form a new structure. Processes include generating, planning, and producing.

\section{Method}

The subject of the study was the implementation of higher order thinking skills in four English language skills which were taught in three different courses namely Word Formation in Modern English course, Varieties of Spoken English and The Principle of Literary Analysis. Word Formation in Modern English course is under Faculty of Classical and Modern Philology, Sofia University, while Varieties of Spoken English and The Principle of Literary Analysis are at Language and Culture program, Department of English and American Studies, Sofia University. Data were collected through documents and observations.

Moreover, data were analyzed from the course description, classroom activities, and assessment using the concept of Bloom's Taxonomy as well as King, Goodson, 


\section{Critical, Logical and Creative Thinking}

and Rohani (2013). They propose some steps in teaching strategies in order to create higher order thinking skills in a classroom. Those teaching strategies comprise: 1) modeling of thinking skills, examples of applied thinking and adaptations for diverse student needs; 2) scaffolding (giving students support at the beginning of a lesson and gradually requiring students to operate independently); 3) useful learning strategies including rehearsal, elaboration, organization, and metacognition; 4) a specifically designed lesson to teach specific learning strategies; 5) sparing direct instruction (teacher-centered presentations of information); 6) short presentations (up to five minutes) with guided practice to teach sub-skills and knowledge; 7) teacher-student generated questions about dilemmas, novel problems, and novel approaches with answers that have not yet been learned; 8) sincere feedback providing immediate, specific, and corrective information as well as informing learners of their progress; 9) small group activities such as student discussions, peer tutoring, and cooperative learning; 10) activities involving challenging tasks (teacher encouragement to stay on task and ongoing feedback about group progress).

\section{FINDINGS}

\section{A. Word English Formation Course}

In the teaching-learning process of Word Formation English course, the lecturer explained the theory or concepts related to how English words are formed, then followed by some real examples. She also invited the students to give more examples and questions from students. This classroom situation was similar throughout the semester. In addition, she also gave assignments to answer some questions that were uploaded in Moodle. The utilization of suitable technology in the instructional design provided more flexibility in the learning environment and influenced the learning outcomes (Alim, Umam \& Wijirahayu, 2016). Both of the task procedures in this study assisted the learners to be more autonomous and creative.

The focus of HOTS used are analyzing, evaluating, and creating in examining the course. From course description, it is clear that the objective of the course was by the end of the semester, students would be able to collect their own small corpus of material, interesting point of view of word-formation, and analyze it. In this case, the key action verb is "collect and analyze" indicating levels four and five on the Bloom's taxonomy rather than having the students simply "Remember" (level one on Bloom's Taxonomy) the different theories by having them select from a pre-made description. 
This allows them to explain the theories in their own words. "Evaluating" the material (level five on Bloom's Taxonomy). Moreover, The level "evaluate" involves the activity of selecting or categorizing. In this case, students were required to categorize words found in their corpus into the right group of word formation.

In addition, there were other indicators that triggered high order thinking skills. It can be seen from the lecturer's modeling on how to analyze words. Scaffolding occured when the lecturer helped the students by showing steps of a word formation. The lecturer always asked the students to give more examples and its analysis and then direct feedback was given. The final assignment and presentation were very challenging because all students had to present their finding completed with their analysis. The enthusiasm of the students in responding the instruction reflected their attitude toward the activities (Wijirahayu \& Dorand, 2018) and positive attitude leads to higher creativity and better performance. Since it was a corpus, students had to carefully read different texts they chose and then were asked to find interesting words to be presented. Students tended to present complex, unique, or new words because they wanted to get a better mark/score.

\section{B. The Varieties of Spoken English}

In this course, the students could practice to enhance four language components. Instead of delivering the course using presentation media, the lecturer also gave tasks to students. The students accessed the tasks given and other information related to the course through e-learning website provided by the university. Ahead the classroom meeting, the lecturer usually uploaded the materials to read and do for the next day lesson. By doing this, the students had extensive practice to improve their reading skills. Similar findings from reflecting activities in improving students' performance in reading has been done by Wijirahayu (2011).

Another strategy used by the lecturer was providing audio-visual media to help better understanding. The lecturer prepared an audio or video recordings of some famous experts and connected them to the whole computer in the classroom. The students were assigned to analyze the accent in the given sheets. Since the course was mainly about pronunciation, the media were really helpful for the students. In addition, an internet connection was provided, so lecturer and students could search everything related to the topic discussed easily. Relating to the use of audio or video as media for the students to get input in listening for improving fluency and 
comprehension, Wijirahayu (2013) argued that the contexts suited to the students' interests eased and motivated the students to achieve instructional goal.

In this case, the lecturer already implemented all levels of Bloom's taxonomy. The lecturer gave question to interact with the students. One of the ways of teaching for deeper understanding and thinking was to allow students to pay an active part in the teaching and learning processes. Good impressions of the students in acquiring new experiences of communicating in English as a foreign language (EFL) their language learning created a prior knowledge that may influence the way they develop the mastery in the future (Wijirahayu, 2017).

\section{The Principle of Literary Analysis}

In the course of The Principle of Literary Analysis, the students discussed mainly about literature such as poem, short story, novel, book, etc. This activity could improve students' reading skill and did analysis better. In every meeting, the students were engaged in interactive learning and the lecturer helped the students interpret the masterpiece that was being discussed. At the end of the course, every student was asked to analyze one of masterpieces chosen by the students themselves and presented it. The tasks given proved that all levels of cognitive dimension have been developed in the course.

Wijirahayu and Ayundhari (2019) also argued that exercises in generating questions, inquiry and discovery stimulated their creative thinking over the learners' research interest. Making justification towards other graduates' work by giving feedback and contributing critiques developed their logical thinking and raising the learners awareness on a reflection of their own ability in writing a research report. Experiences in attending courses of research method and thesis writing overseas have created different learners' mindset about classroom practices. Creative thinking in this case was developed by the lecturers as well as the students suitable to the nature of the subject matter. Adjusting the supported learning environment set systematically to build creative thinking and cultural awareness in any other challenging EFL contexts are suggested for further application.

\section{CONCLUSION}

Word Formation course has a seminal objective of requiring the students to be able to collect their own small corpus of material, interesting ideas from the point of view of word-formation, and analyze it. To achieve this objective, the lecturers in the study applied some teaching strategies that are mostly categorized HOTS and the 
students were also required to think in the level of HOTS. The thinking skills were also implemented in the Language and Culture program at the Department of English and American Studies, Sofia University. By taking the course of the Varieties of Spoken English, students were supposed to enhance the four language skills: reading, listening, writing and speaking. Involving the students to play an active part in the teaching and learning processes is one of the ways. Additionally, assigning every student to analyze and present a selected literary work based on their interest proved that all levels of cognitive dimension have been developed in the course of the Principle of Literary Analysis. Some improvements are suggested to do for, either, the lecturers and the students to achieve higher-order thinking skills.

\section{REFERENCES}

Alim, E.S., Umam, K. \& Wijirahayu,S. (2016). The Imlementation of Blended Learning Instruction by Utilizing WeChat Application. Proceeding of the $24^{\text {th }}$ International Conference.

Anderson, L. W., \& Krathwohl, D. R. (Eds.). (2001). A taxonomy for learning, teaching, and assessing: A revision of Bloom's Taxonomy of Educational Objectives (Complete ed.). New York: Longman.

Brookhart, S. M. (2010). How to Assess Higher-Order Thinking Skills in Your Classroom. Alexandria,VA: ASCD.

http://www.ascd.org/publications/books/109111/chapters/Introduction.aspxCo mputers in Education ICCE (100- 107).

Goethals, P. (2013). The Pursuits of Higher Order Thinking in Mathematics

Classroom: A Review. Retrieved from: http://www.usma.edu/cfe/literature/goethals_13.pdf

Hancock, G. R. (1994). Cognitive complexity and the comparability of multiplechoice and constructed-response test formats. Journal of Experimental Education, 62(2). 143-157.

King, F.J., Goodson, L. \& Rohani, F., (2013). Higher order thinking skills. Center for Advancement of Learning and Assessment. Retrieved from: http://www.cala.fsu.edu/files/higher_order_thinking_skills.pdf

Paul, R., \& Nosich, R. (1992). A model for the national assessment of higher order thinking. (ERIC Document Reproduction Service No. ED 353 296).

Shavelson, R. J., Baxter, G. P., \& Gao, X. (1993). Sampling variability of performance assessments. Journal of Educational Measurement, 30(3), 215-232.

Sugrue, B. (1995). A theory-based framework for assessing domain-specific problemsolving ability. Educational Measurement: Issues and Practices, 14(3), 29-36.

Wijirahayu, S. \& Ayundhari, V. (2019). Classroom Experience of Creative Thinking. UICELL Proceeding 2018. https://journal.uhamka.ac.id/index.php/uicell/article/view/2546

Wijirahayu, S. \& Dorand, P. (2018). Affective Strategies, Attitude and A Model of Speaking Performance Development for Engineering Students. Journal of Physic Conference series 948 (2018) 012024. 
Critical, Logical and Creative Thinking

Wijirahayu, S. (2011). Peningkatan Kemampuan Membaca Bahasa Inggris Mahasiswa Pasca Sarjana Dengan One-time Strategy Training. Journal Penelitian Inovasi dan Perekayasa Pendidikan. No.6 (2).

Wijirahayu, S. (2013). Pre-service Teachers Beliefs' in Utilizing Film and Role-play in EFL Classroom Practices. Proceeding International Conference on Computer in Education (ICCE).

Wijirahayu, S. (2017). Strategi Belajar Bahasa Inggris sebagai Bahasa Asing dari Perspektif Keyakinan Guru. Proceeding Konferensi Nasional Pascasarjana PTM ke-5 di Sidoarjo.

Wijirahayu, S. (2017). Teachers' Prior Knowledge Influence in Promoting English Learning Strategies. Journal Penelitian Inovasi Pendidikan Dasar. Vol.2 (2). Page 45-52. 